\title{
Evaluation of Core Competence of Cold-Chain Logistics Enterprises Based on FCE Model
}

\author{
Sun Jian and Zhou Jing*
}

School of Economic Management, Shenyang Agricultural University, Shenyang, Liaoning, 110866, China

\begin{abstract}
The development of cold-chain logistics will not only contribute to solving the food safety problems, but also effectively promote the development of agriculture industry and animal husbandry industry. In order to be well informed of the core competence in cold-chain logistics enterprise, we evaluated the competence of cold-chain logistics enterprise in China with the combination of analytic hierarchy process (AHP) methods and fuzzy comprehensive evaluation (FCE) modeling. Then, we took a typical cold-chain logistics enterprise as an example. We find that the core competence of that cold-chain logistics enterprise is not very outstanding through investigation and evaluation. In the end, we propose several suggestions about the development pattern of cold-chain logistics enterprises on the basis of investigating and modeling results.
\end{abstract}

Keywords: AHP methods, cold-chain logistics enterprise, FCE model.

\section{INTRODUCTION}

Along with domestic economic development and satisfaction of basic daily needs, people increasingly pay attention to the improvement of quality of life. The food safety problems in recent years have become a serious threat to people's health and quality of life, thus making production, delivery, restoration and sales of perishables, including vegetables, fruits and dairy products, focus of attention. A meeting with the theme of "Consumer Safety \& Safety Advantages" was organized during the World Economic Forum at Dovas on September 10, 2014, pointing out that the food safety problem is not only a question of principle but a question of capability. Development of cold-chain logistics will make major contributions to solving food safety problems.

Cold-chain logistics started relatively late in China, but has developed by leaps and bounds. The need of cold-chain logistics market has accelerated with the annual increase of $20 \%$ [1]. According to a survey conducted by National Coldchain Logistics Alliance of China in 2014, the total refrigeratory storage of 680 major cold-chain logistics enterprises amounts to $20,469,713$ tons $\left(57,546,093 \mathrm{~m}^{3}\right)$ with 29,444 refrigerator cars, which implies that cold-chain logistics has formed a certain scale in China. There are up to 700 coldchain logistics enterprises of different scales in China at present, among which large-scaled enterprises account for a small proportion. Technologically speaking, China still considerably lags behind developed countries in this industry [2]. Scientific evaluation on the core competence of coldchain logistics enterprises and dynamic management based on actual conditions shall accelerate development of those enterprises. Based on features of cold-chain logistics enterprises and AHP methods, this paper builds an appropriate evaluation indicator system and evaluates core competence of cold-chain logistics enterprises with fuzzy comprehensive evaluation (FCE) modeling.

\section{BUILDING EVALUATION INDICATOR SYSTEM BASED ON AHP METHODS}

Before evaluating the core competence of enterprises, a scientific and reasonable evaluation index system should be built so as to demonstrate the inner specific value of each enterprise objectively and scientifically and find out the elements that make an enterprise become competent or keep competent in this field [3]. Combining general elements of core competence of enterprises with specific features of cost, technology and environment of cold-chain logistics, this paper divides indicators which constitute the core competence of cold-chain logistics enterprises into the following groups: finance indicators, management indicators, operation indicators, service indicators and personnel indicators [4].

Finance indicators are composed of cash flow ratio, total assets increase rate and liquidity ratio, which shall be helpful to evaluate the core competence of cold-chain logistics enterprises comprehensively and objectively. Management indicators are composed of social accumulation rate, logistics profit rate and social contribution rate, which shall present the management level and creativity level of logistics enterprises from the perspective of the whole market and logistics enterprises. Operation indicators are composed of refrigeratory utilization ratio, refrigerator car utilization ratio, food defect ratio and inventory turnover rate, which are put forward based on the business features of cold-chain logistics enterprises. Operation of cold-chain logistics covers different activities such as low temperature storage and low temperature delivery and thus requires a high level of technology and equipment. Refrigeratory utilization ratio and 


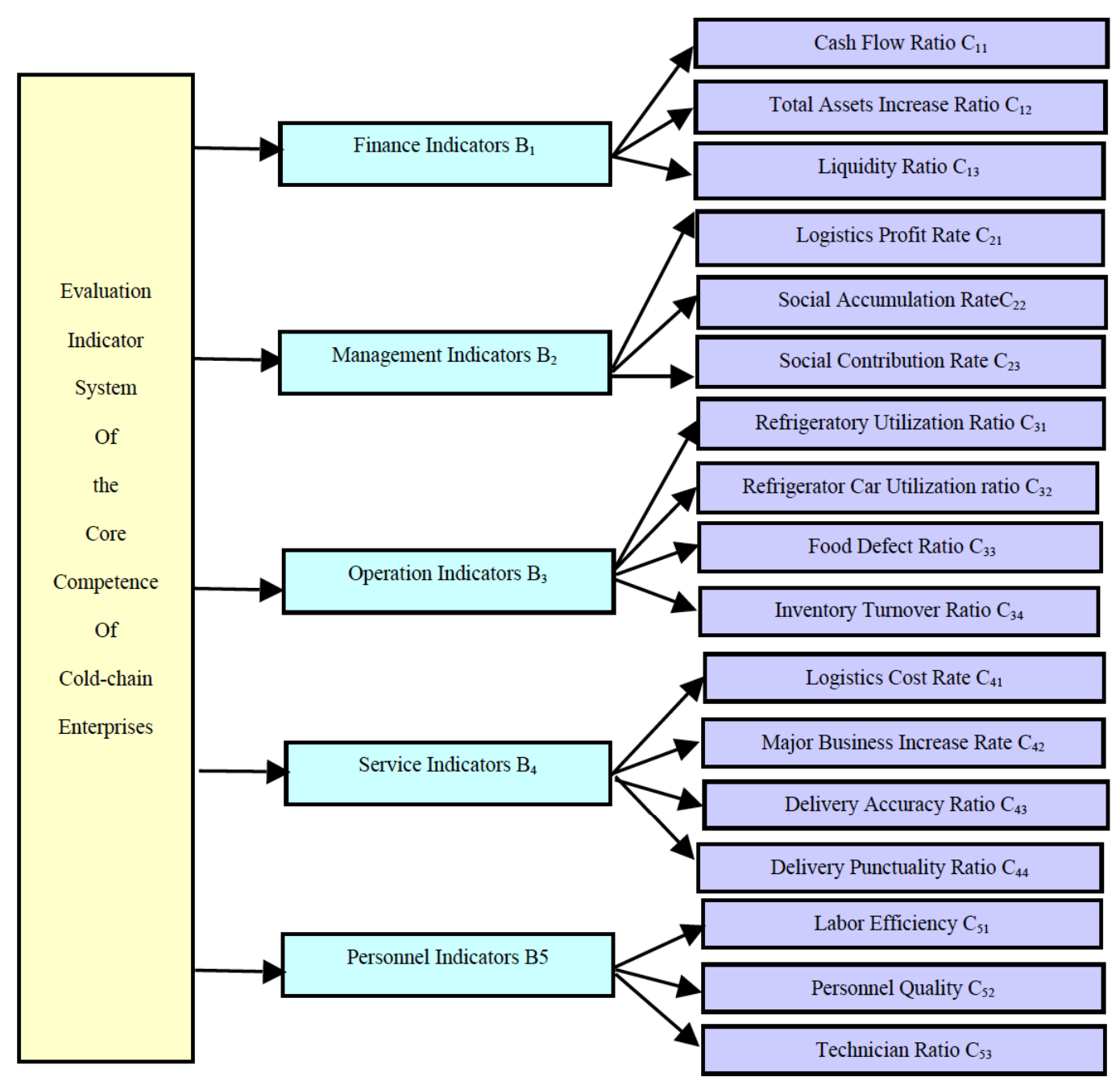

Fig. (1). Evaluation indicator system of the core competence of cold-chain logistics enterprises.

refrigerator car utilization ratio shall be adopted to evaluate cold-chain operation of enterprises. Service indicators are composed of logistics cost rate, major business profit rate, delivery accuracy ratio and delivery punctuality ratio, which shall demonstrate whether the evaluated enterprises are capable of meeting the requirement of consumers or not and whether the logistics service is of high quality or not from various aspects [5]. Personnel indicators are composed of labor efficiency, personnel quality and technician ratio, which shall reflect the investment on personnel of cold-chain logistics enterprises and the comprehensive quality, work efficiency and work competence of personnel. The indicator system formed by the 17 indicators of the five levels mentioned above combines the core competence of enterprises with business specialty of cold-chain logistics to reflect the core competence of a cold-chain logistics enterprise comprehensively and systematically. Fig. (1) demonstrates the evaluation indicator system of the core competence of coldchain logistics enterprises as follows:

The weight of each indicator should be confirmed after the evaluation indicator system is built. Confirmation of weight shall be the key to evaluation quantification. Various ways can be adopted to confirm the weight of each indicator, mainly including subjective weight and objective weight.
The former may come from expert consultation, Delphi method or analytic hierarchy process while the latter may come from the maximum entropy, major ingredient analysis or multi-objective planning etc [6]. Each method possesses its own unique feature. On account of the fact that currently the cold-chain logistics enterprises in China are mostly of small scale and there is no integrated industry system which may hinder data collection, analytic hierarchy process (AHP) shall be adopted to confirm the weight of each indicator.

AHP is a qualitative and quantitative decision analysis method which is often adopted to solve sophisticated and multi-objective problems in production and life. Decisionmakers should empirically judge the relative importance of various indicators concerning the realization of targets and reasonably confirms the relative weight of each indicator of each program to figure out the superior sequence of each program [7]. Thus building of evaluation indicators concerning core competence of cold-chain logistics enterprises includes the following four steps.

\section{Step 1: Building of Hierarchy Structure Model}

A hierarchy structure model should be built first for methodization of the system issues. According to different targets, elements and decision objects, the hierarchy structure 
Table 1. Scale table of 1-9.

\begin{tabular}{|c|c|c|c|c|c|c|c|c|c|}
\hline Scale $\mathbf{a}_{\mathbf{i j}}$ & $\mathbf{1}$ & $\mathbf{2}$ & $\mathbf{3}$ & $\mathbf{4}$ & $\mathbf{5}$ & $\mathbf{6}$ & $\mathbf{7}$ & $\mathbf{8}$ & $\mathbf{9}$ \\
\hline \hline $\begin{array}{c}\text { Importance } \\
\text { of B: B }\end{array}$ & equal & & $\begin{array}{c}\text { slightly } \\
\text { higher }\end{array}$ & & stronger & & $\begin{array}{c}\text { obviously } \\
\text { higher }\end{array}$ & $\begin{array}{c}\text { absolutely } \\
\text { higher }\end{array}$ \\
\hline
\end{tabular}

can be divided into three levels, the top level, the mediate level and the bottom level. The evaluation indicator system of core competence of cold-chain logistics enterprises as showed in chart 1 can be compared to a structure model. The top level of the model is evaluation of core competence of cold-chain logistics enterprise. The mediate level includes finance indicators, management indicators, operation indicators, service indicators and personnel indicators. The 17 specific indicators form the bottom level of the structure model (Table 1). trices.

Step 2: Building of Judgment (Paired Comparison) Ma-

After the hierarchy structure is confirmed, the five elements of B1, B2, B3, B4, B5 are compared in pairs to measure their importance based on the principle of the core competence of a cold-chain logistics enterprise. As for $\mathrm{A}$, the core competence of the cold-chain logistics enterprise, the five compared elements form a paired comparison matrix as follows:

$$
A ? i a_{i j} ? \dot{5} \times 5
$$

$A_{i j}$ is the scale of importance of $B_{i}$ and $B_{j}$ relative to $A$. A is the positive reciprocal matrix, with $\mathrm{a}_{\mathrm{ij}}>0$ and $\mathrm{a}_{\mathrm{ij}}=1 / \mathrm{a}_{\mathrm{ji}}$. As the maximum in a scale table is usually 9 , it is better to set no more than 9 elements for each level. The following is the scale table of 1-9 (Table 2) and the meaning of each even number, that is, scale 2 , scale 4 , scale 6 and scale 8 , is between that of the odd numbers immediately next to it.

Step 3: Calculation of Single Hierarchical Arrangement and Test of Coherence

Hierarchical weight should be figured out after building of judgment (Paired Comparison) matrix. Calculation of weight is conducted hierarchically by AHP, from the top to the bottom. The weight of influence of the five indicators in Level B on the core competence of cold-chain logistics enterprises can be calculated by addition, power method or extraction of root. The weight vector $(\omega)$ can be gained in the three mentioned ways as follows:

$\omega=\left(\omega_{1} ? C \omega_{2} ? C \omega_{3} ? C \omega_{4} ? C \omega_{5}\right)$

Reciprocal or complementary matrices are called coherence matrices, which can be processed in normalization. The weight shall be calculated with normalization method by AHP only in the condition that the matrices are coherent. It is found that paired matrices are usually not coherent. But it is feasible once the degree of incoherence is within bounds. So test of coherence of matrices should be taken. When the test parameter $\mathrm{CI}=0$, the matrix is coherent. The higher the value of CI is, the higher the degree of incoherence.

$C I=\frac{\lambda_{\max }-n}{n-1}$

\section{Suppose}

$C R=\frac{C I}{R I}$

$\mathrm{CR}$ as the coherence ratio, $\mathrm{RI}$ as the random coherence parameter. When $\mathrm{CR}<0.1$, the degree of incoherence is considered to be within bounds. The value of RI can be attained by table look-up.

After calculation of the weights of the five indicators in Level B and test of coherence of relative judgment matrix, the weight of influence of the 17 specific indicators in Level $\mathrm{C}$ on the five indicators in Level $\mathrm{B}$ are calculated. The respective results are as follows:

$$
\begin{aligned}
& \omega_{1}=\left(\omega_{11} ? C \omega_{12} ? C \omega_{13}\right) \\
& \omega_{2}=\left(\omega_{21} ? C \omega_{22} ? C \omega_{23}\right) \\
& \omega_{3}=\left(\omega_{31} ? C \omega_{32} ? C \omega_{33} ? C \omega_{34}\right) \\
& \omega_{4}=\left(\omega_{41} ? C \omega_{42} ? C \omega_{43} ? C \omega_{44}\right) \\
& \omega_{5}=\left(\omega_{51} ? C \omega_{52} ? C \omega_{53}\right)
\end{aligned}
$$

Step 4: Calculation of Total Hierarchical Arrangement Weight Vector

Hierarchical calculation of weight in Level $\mathrm{C}$ is not the final target of the evaluation. The weights in Level $\mathrm{C}$ should be combined with those in Level B to explain how the 17 specific indicators in Level $\mathrm{C}$ influence the core competence of cold-chain enterprises. In this way, quantitative and qualitative methods are combined to divide the task into various components and processed by AHP methods according to their relative and subordinative relationships [8]. When hierarchy of core competence of cold-chain enterprises is arranged, the relative indicators are divided into five groups in Level B and 17 in Level C thus to pave way for fuzzy comprehensive evaluation (FCE) modeling.

\section{EVALUATION OF CORE COMPETENCE OF COLD-CHAIN LOGISTICS ENTERPRISES BASED ON FCE MODELLING}

Various ways can be adopted to evaluate the core competence of cold-chain logistics enterprises such as BP neural network, matter element analysis, data envelopment analysis and fuss comprehensive evaluation (FCE). Each method possesses its unique advantages and disadvantages [9]. As the concept of core competence is relatively obscure, FCE modeling is adopted in this paper to evaluate and study the core competence of cold-chain logistics enterprises.

FCE is a comprehensive evaluation method of fuzzy mathematics. It quantizes the fuzzy qualitative concepts in- 
fluenced by many factors with grade of membership theory to make overall evaluation of the influence of each indicator on fuzzy concepts clearly and systematically. It has a wide range of application in production and daily life. Evaluation of the core competence of cold-chain logistics enterprises with FCE modeling means quantization of the fuzzy concept of core competence and overall evaluation of all the indicators that influence the core competence of a cold-chain logistics enterprise based on the weight calculated by AHP methods [10]. According to the evaluation indicator system of the core competence of cold-chain logistics enterprises mentioned above, the set of evaluated indicators can be confirmed as follows:

$\mu=\left(\mu_{1 ?} \mu_{2 ?} \mu_{3 ?} \mu_{4 ?} \mu_{5}\right)$

The competence of each mediate level can be divided into the following indicators:

$$
\begin{aligned}
& \mu_{1}=\left(\mu_{11} ? q \mu_{12} ? q \mu_{13}\right) \\
& \mu_{2}=\left(\mu_{21} ? q \mu_{22} ? q \mu_{23}\right) \\
& \mu_{3}=\left(\mu_{31} ? q \mu_{32} ? q \mu_{33} ? q \mu_{34}\right) \\
& \mu_{4}=\left(\mu_{41} ? q \mu_{42} ? q \mu_{43} ? q \mu_{44}\right) \\
& \mu_{5}=\left(\mu_{51} ? q \mu_{52} ? q \mu_{53}\right)
\end{aligned}
$$

A remark set is a qualitative description of the content of a factor set. The remark set of core competence of cold-chain logistics enterprises is as follows:

$$
P=\left(P_{1} ? C P_{2} ? C P_{3} \ldots P_{m}\right)
$$

$\mathrm{Pm}$ is the fuzzy comprehensive evaluation of the core competence of cold-chain logistics enterprises from the angle of $\mu \mathrm{i}$. There is qualitative description of the influence of each indicator in Level $\mathrm{C}$ on the core competence of coldchain logistics enterprises. With reference to general evaluation, the following remark set can be determined:

\section{$\mathrm{P}=($ Very High, High, Ordinary, Low, Very Low $)$}

After determining the remark set, each remark is graded to form the grade set as follows:

$$
\mathrm{S}=(90,80,70,60,50)
$$

Make fuzzy evaluation of each second-level indicator to determine the grade of membership of relative remark sets and rij is attained to form the following fuzzy evaluation judgment matrix R:

$$
R=\left(\begin{array}{l}
r_{11}, r_{12}, \ldots, r_{15} \\
r_{21}, r_{22}, \ldots, r_{25} \\
\ldots \\
r_{n 1}, r_{n 2}, \ldots, r_{n 5}
\end{array}\right)
$$

For $\mathrm{r}_{\mathrm{ij}}, \mathrm{i} \in(1,17), \mathrm{j} \in(1,5)$.

The final comprehensive result can be determined with an appropriate operator mode based on the weight vector $\omega$ which is determined by AHP methods.
$\mathrm{D}=\omega^{*} \mathrm{R}=\left(\mathrm{d}_{1}, \mathrm{~d}_{2}, \ldots \mathrm{d}_{\mathrm{n}}\right)$. The evaluation result is determined by $R$ and $\omega$. Eventually after the normalization processing of $\mathrm{D}$, the final evaluation result of the core competence of cold-chain logistics enterprises can be determined.

\section{CASE OF EVALUATION OF CORE COMPETENCE OF COLD-CHAIN LOGISTICS ENTERPRISES}

\subsection{Enterprise Profile}

Cold-chain logistics company A is a subsidiary corporation of a large-scaled logistics enterprise with registered capital of $¥ 40$ million. Its main business is delivery and storage of cold-chain products. Since it was founded, the company has invested a lot of money and technology to develop cold-chain logistics relying on its unique geographical and resource advantages. In order to better carry out national industrial policies, the company has increased investment to purchase adequate refrigerator cars for operation and to build refrigerator houses and food processing centre, logistics centre, testing centre, exhibition centre and comprehensive management service centre, container yard and relevant facilities as well. The company will seek for further professional development to meet the opportunities and challenges of the market with professional equipment and service. In 2013, the company invested more than 4,000 new refrigerator cars to make growth of $24.29 \%$ of the gross margin from special container business while $4.09 \%$ of gross profit rate.

In 2012, the company was chosen by the National Cold Chain Logistics Alliance of China to be one of the top 50 cold-chain logistics enterprises in China. For better development of the company and improvement of management of capital, technology, marketing and personnel, the evaluation of the core competence in the industry of the company is conducted to have scientific, objective and further insight into the present situation of it.

\subsection{Building Evaluation Indicator System of Core Com- petence of the Company by AHP}

Based on the introduction of the model, AHP methods and FCE modeling are combined to evaluate the core competence of the company. According to the evaluation indicator system of cold-chain logistics enterprises demonstrated in Fig. (1), the factor set of the evaluation is as follows:

$A=\left(\right.$ Finance Indicators $B_{1}$, Management Indicators $B_{2}$, Operation Indicators $\mathrm{B}_{3}$, Service Indicators $\mathrm{B}_{4}$, Personnel Indicators $\mathrm{B}_{5}$ )

$\mathrm{B} 1=\left(\right.$ Cash flow Ratio $\mathrm{C}_{11}$, Total Assets Increase Rate $\mathrm{C}_{12}$, Liquidity Ratio $\mathrm{C}_{13}$ )

$\mathrm{B} 2=\left(\right.$ Social Accumulation Rate $\mathrm{C}_{21}$, Logistics Profit Rate $\mathrm{C}_{22}$, Social Contribution Rate $\mathrm{C}_{23}$ )

$\mathrm{B} 3=\left(\right.$ Refrigeratory Utilization Ratio $\mathrm{C}_{31}$, Refrigerator Car Utilization Ratio $\mathrm{C}_{32}$, Food Defect Ratio $\mathrm{C}_{33}$, Inventory Turnover Rate $\mathrm{C}_{34}$ )

B4= (Logistics Cost Rate $\mathrm{C}_{41}$, Major Business Profit Rate $\mathrm{C}_{42}$, Delivery Accuracy Ratio $\mathrm{C}_{43}$, Delivery Punctuality Ratio $\mathrm{C}_{44}$ )

B5 $=\left(\right.$ Labor Efficiency $\mathrm{C}_{51}$, Personnel Quality $\mathrm{C}_{52}$, Technician Ratio $\mathrm{C}_{53}$ ) 
Table 2. A-B judgment matrix.

\begin{tabular}{|c|c|c|c|c|c|}
\hline $\mathbf{A}$ & $\mathbf{B 1}$ & $\mathbf{B 2}$ & $\mathbf{B 3}$ & $\mathbf{B 4}$ & $1 / 2$ \\
\hline \hline B1 & 1 & $1 / 2$ & $1 / 3$ & $1 / 4$ & $1 / 2$ \\
\hline B2 & 2 & 1 & $1 / 5$ & 3 \\
\hline B3 & 3 & 5 & $1 / 3$ & 1 & 2 \\
\hline B4 & 2 & 4 & $1 / 2$ & $1 / 2$ & 1 \\
\hline B5 & 2 & 4 & & $1 / 4$ \\
\hline
\end{tabular}

Table 3. Judgment matrix $B_{1}$ and weight of each indicator.

\begin{tabular}{|c|c|c|c|c|}
\hline B1 & C1 & C2 & C3 & 5 \\
\hline \hline C1 & 1 & 4 & 2 & 0.709 \\
\hline C2 & $1 / 4$ & 1 & 1 & 0.177 \\
\hline C3 & $1 / 5$ & $1 / 2$ & 0.114 \\
\hline
\end{tabular}

Table 4. Judgment matrix $B_{2}$ and weight of each indicator.

\begin{tabular}{|c|c|c|c|c|}
\hline B1 & C1 & C2 & C3 & Weight \\
\hline \hline C1 & 1 & 2 & $1 / 2$ & 0.490 \\
\hline C2 & $1 / 2$ & 1 & 1 & 0.198 \\
\hline C3 & $1 / 2$ & 2 & 0.952 \\
\hline
\end{tabular}

With advice from experts in this field, the judgment matrix of the top level (Matrix A-B) is determined as follows Table 2:

\subsection{Calculation of Weight of Each Level and Test of Co- herence of Matrix}

The weight $\omega$ of Level $B$ to the original matrix A is determined by addition after the judgment matrix is determined. The weight vector set after normalization is as follows:

Test of coherence should be conducted with relevant indicators after weight calculation to determine whether the matrix is within bounds. In the case that the coherence is not within bounds, the original matrix should be modified.

In order to test the coherence of the matrix, multiply A by $\omega$ to get the following vector:

As $\mathrm{A} \omega=\lambda^{*} \omega$, it can be determined that the maximum eigenvalue of the matrix $\lambda$ is 6.674 .

$\omega=(0.092,0.089,0.397,0.231,0.191)$

$A \omega=(0.480,0.457,2.192,1.285,1.044)$

According to the table of random coherence indicator RI by Saaty, when $\mathrm{n}=5, \mathrm{RI}=1.12$,

$C I=\frac{\lambda_{\max }-n}{n-1}=\frac{5.383-5}{5-1}=0.096$
$C R=\frac{C I}{R I}=\frac{0.096}{1.12}=0.0856$

When $\mathrm{CR}<0.1$, the degree of incoherence of Matrix $\mathrm{A}$ is within bounds. The weight of each indicator in Matrix $B_{1}$, Matrix $\mathrm{B}_{2}$, Matrix $\mathrm{B}_{3}$, Matrix $\mathrm{B}_{4}$, Matrix $\mathrm{B}_{5}$ is calculated with the same approach and the coherence of each matrix is tested.

The result of Judgment Matrix $\mathrm{B}_{1}=\left(\right.$ Cash flow Ratio $\mathrm{C}_{11}$, Total Assets Increase Rate $\mathrm{C}_{12}$, Liquidity Ratio $\mathrm{C}_{13}$ ) is as follows Table 3:

$\mathrm{CI}=0.0186 . \quad \mathrm{CR}=\mathrm{CI} / \mathrm{RI}=0.0186 / 0.58=0.0322<0.1 . \quad \mathrm{Judg}-$ ment Matrix B1 is coherent.

The result of Judgment Matrix B2 $=($ Social Accumulation Rate $\mathrm{C}_{21}$, Logistics Profit Rate $\mathrm{C}_{22}$, Social Contribution Rate $\mathrm{C}_{23}$ ) is as shown in Table 4:

$\mathrm{CI}=0.0269 . \quad \mathrm{CR}=\mathrm{CI} / \mathrm{RI}=0.0269 / 0.58=0.0463<0.1 . \mathrm{Judg}-$ ment Matrix B2 is coherent. The result of Judgment Matrix $\mathrm{B} 3=\left(\right.$ Refrigeratory Utilization Ratio $\mathrm{C}_{31}$, Refrigerator Car Utilization Ratio $\mathrm{C}_{32}$, Food Defect Ratio $\mathrm{C}_{33}$, Inventory Turnover Rate $\mathrm{C}_{34}$ ) is as shown in Table 5:

$\mathrm{CI}=0.0154 . \quad \mathrm{CR}=\mathrm{CI} / \mathrm{RI}=0.0154 / 0.9=0.0172<0.1 . \quad J u d g-$ ment Matrix B3 is coherent. The result of Judgment Matrix B4=(Logistics Cost Rate $\mathrm{C}_{41}$, Major Business Profit Rate $\mathrm{C}_{42}$, Delivery Accuracy Ratio $\mathrm{C}_{43}$, Delivery Punctuality Ratio $\mathrm{C}_{44}$ ) is as shown in Table 6: 
Table 5. Judgment matrix $B_{3}$ and weight of each indicator.

\begin{tabular}{|c|c|c|c|c|c|}
\hline B1 & C1 & C2 & C3 & Weight & 2 \\
\hline \hline $\mathrm{C} 1$ & 1 & 2 & 4 & $1 / 2$ & 0.429 \\
\hline $\mathrm{C} 2$ & $1 / 2$ & 1 & 1 & $1 / 3$ & 0.183 \\
\hline $\mathrm{C} 3$ & $1 / 4$ & $1 / 2$ & 3 & 1 & 0.097 \\
\hline $\mathrm{C} 4$ & $1 / 2$ & 2 & & 0.291 \\
\hline
\end{tabular}

Table 6. Judgment matrix $B_{4}$ and weight of each indicator.

\begin{tabular}{|c|c|c|c|c|c|}
\hline B1 & C1 & C2 & C3 & C4 & 5 \\
\hline \hline $\mathrm{C} 1$ & 1 & 1 & 2 & 3 & 0.402 \\
\hline $\mathrm{C} 2$ & 1 & 1 & 1 & 2 & 0.344 \\
\hline $\mathrm{C} 3$ & $1 / 2$ & $1 / 4$ & $1 / 2$ & 1 & 0.167 \\
\hline $\mathrm{C} 4$ & $1 / 5$ & $1 / 3$ & 0.087 \\
\hline
\end{tabular}

Table 7. Judgment matrix $B_{5}$ and weight of each indicator.

\begin{tabular}{|c|c|c|c|c|}
\hline B1 & C1 & C2 & W3 & 4 \\
\hline C1 & 1 & 3 & 1 & 0.633 \\
\hline \hline C2 & $1 / 3$ & 1 & 1 & 0.192 \\
\hline C3 & $1 / 4$ & 1 & 1 & 0.175 \\
\hline
\end{tabular}

$\mathrm{CI}=0.0498 . \mathrm{CR}=\mathrm{CI} / \mathrm{RI}=0.0553<0.1$. Judgment Matrix $\mathrm{B}_{4}$ is coherent.

The result of Judgment Matrix $\mathrm{B}_{5}=\left(\right.$ Labor Efficiency $\mathrm{C}_{51}$, Personnel Quality $\mathrm{C}_{52}$, Technician Ratio $\mathrm{C}_{53}$ ) is as shown in Table 7:

$\mathrm{CI}=0.0046 . \quad \mathrm{CR}=\mathrm{CI} / \mathrm{RI}=0.0046 / 0.58=0.0079<0.1 . \quad \mathrm{Judg}-$ ment Matrix $\mathrm{B}_{5}$ is coherent.

The weight of each indicator in Level $\mathrm{C}$ to the evaluation of the core competence of the company can be determined by integrating the above results. The result is as follows in Table 8:

\subsection{Calculation of Core Competence of the Company of FCE}

Evaluation of core competence by FCE is carried out after calculation of the indicator weights. In the above introduction of the model, the remark set $\mathrm{P}$ is built as follows: $\mathrm{P}=($ Very High, High, Ordinary, Low, Very Low $)$. In addition, each remark of different levels is graded as shown in Table 9:

The specific description data of the 17 indicator is drawn from investigation and conversations with relevant personnel of the evaluated company. Fuzzy Judgment Matrix R17*5 is obtained after data analysis as follows Table $\mathbf{1 0 .}$

According to the formula
$\mathrm{D}=\omega * \mathrm{R}$,

With $\omega$ as the integrated weight vector of indicators in Level $\mathrm{C}$ as demonstrated in Table $\mathbf{1 0}, \mathrm{R}$ as the vector formed by the remark grade of each indicator in Table 9.

Then it can be drawn that $\mathrm{D}=\omega_{1} * 17 * \mathrm{R}_{17} * 5$, with $\mathrm{D}$ as a vector of $1 * 5$. The calculating result by software is:

$\mathrm{D}=(0.4227,0.1909,0.1366,0.1444,0.1707)$

With normalization,

$\mathrm{D}=(0.3968,0.1792,0.1282,0.1356,0.1603)$

Combine the remark set and the following formula:

$S=\sum_{i=1}^{n} P_{i} d_{j}$

$\mathrm{j}=(1,2, \ldots, \mathrm{n})$

$\mathrm{j}=(1,2,3,4,5)$

$\mathrm{N}=5$

$\mathrm{P}=(90,80,70,60,50)$

$\mathrm{D}=(0.3968,0.1792,0.1282,0.1356,0.1603)$

The result of comprehensive evaluation is as follows:

$\mathrm{S}=0.3969 * 90+0.1792 * 80+0.1282 * 70+0.1356 * 60+0.1603$ $* 50=75.167$. 
Table 8. Weight of each indicator.

\begin{tabular}{|c|c|c|c|c|}
\hline \multirow{11}{*}{ 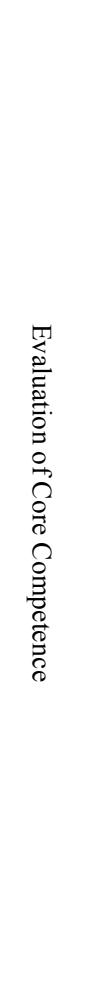 } & \multirow{2}{*}{$\begin{array}{c}\text { Finance Indicators } \\
0.0915\end{array}$} & Cash flow Ratio & 0.7084 & 0.0648 \\
\hline & & Liquidity Ratio & 0.1144 & 0.0105 \\
\hline & $\begin{array}{c}\text { Management Indicators } \\
0.0889\end{array}$ & Social Contribution Rate & 0.3119 & 0.0277 \\
\hline & \multirow{2}{*}{$\begin{array}{l}\text { Operation Indicators } \\
0.3973\end{array}$} & Refrigeratory Utilization Ratio & 0.4292 & 0.1705 \\
\hline & & Refrigerator Car Utilization Ratio & 0.1833 & 0.0728 \\
\hline & \multirow{3}{*}{$\begin{array}{c}\text { Service Indicators } \\
0.2310\end{array}$} & Major Business Profit Rate & 0.4411 & 0.1019 \\
\hline & & Delivery Accuracy Ratio & 0.2139 & 0.0494 \\
\hline & & Delivery Punctuality Ratio & 0.1124 & 0.0260 \\
\hline & \multirow{3}{*}{$\begin{array}{l}\text { Personnel Indicators } \\
0.1913\end{array}$} & Labor Efficiency & 0.6328 & 0.121 \\
\hline & & Personnel Quality & 0.1924 & 0.0368 \\
\hline & & Technician Ratio & 0.1749 & 0.0334 \\
\hline
\end{tabular}

Table 9. Corresponding grade of remark set of core competence evaluation of company A.

\begin{tabular}{|c|c|c|c|c|c|}
\hline Remark Set & Very High & High & Ordinary & Low & Very Low \\
\hline \hline Grade & 90 & 80 & 70 & 60 & 50 \\
\hline
\end{tabular}

Table 10. Fuzzy judgment matrix $R$.

\begin{tabular}{|c|c|c|c|c|c|}
\hline $\begin{array}{c}\text { Indicators } \\
\text { (Level C) }\end{array}$ & Very High & High & Ordinary & Low & 0.1 \\
\hline \hline Cash flow Ratio & 0.4 & 0.2 & 0.2 & 0.2 & 0.1 \\
\hline Total Assets Increase Rate & 0.3 & 0.2 & 0.2 & 0.1 & 0.1 \\
\hline Liquidity Ratio & 0.5 & 0.1 & 0.1 & 0.1 & 0.1 \\
\hline Social Accumulation Rate; & 0.5 & 0.2 & 0.2 & 0.1 & 0.1 \\
\hline Logistics Profit Rate; & 0.3 & 0.2 & 0.1 & 0.1 \\
\hline Social Contribution Rate & 0.3 & 0.3 & 0.1 & 0.1 \\
\hline Refrigeratory Utilization Ratio; & 0.3 & 0.3 & 0.1 & 0.1 \\
\hline Refrigerator Car Utilization Ratio; & 0.6 & 0.1 & 0.1 & 0.1 \\
\hline Food Defect Ratio; & 0.4 & 0.1 & 0.1 & 0.1 \\
\hline Inventory Turnover Rate & 0.3 & 0.2 & 0.1 & 0.1 \\
\hline Logistics Cost Rate; & 0.4 & & & 0.1 \\
\hline
\end{tabular}


Table 10. Contd.....

\begin{tabular}{|c|c|c|c|c|c|}
\hline $\begin{array}{l}\text { Indicators } \\
\text { (Level C) }\end{array}$ & Very High & High & Ordinary & Low & Very Low \\
\hline Major Business Profit Rate; & 0.5 & 0.1 & 0.1 & 0.2 & 0.1 \\
\hline Delivery Accuracy Ratio; & 0.4 & 0.1 & 0.2 & 0.1 & 0.2 \\
\hline Delivery Punctuality Ratio & 0.6 & 0.1 & 0.1 & 0.1 & 0.1 \\
\hline Labor Efficiency; & 0.4 & 0.1 & 0.1 & 0.2 & 0.2 \\
\hline Personnel Quality; & 0.2 & 0.2 & 0.2 & 0.3 & 0.1 \\
\hline Technician Ratio & 0.5 & 0.2 & 0.1 & 0.1 & 0.1 \\
\hline
\end{tabular}

Based on the value of $S$, the conclusion can be drawn that the core competence of the cold-chain logistics company is ordinary.

\subsection{Result Analysis}

From the results, the measures of the degrees "Very High", "High", "Ordinary", "Low" and "Very Low" are respectively $0.3968,0.1792,0.1282,0.1356,0.1603$. The quantitative result is 75.167 by method of weighted average, from which we know the clod-chain logistics company is ordinary.

From the results listed in Table 2, it can be seen that the weights of operation indicators and service indicators offered by experts are relatively large, 0.397 and 0.231 respectively, which gives the clues that operation and service play important roles in the core competence of a cold-chain logistics enterprise. As is mentioned above, the evaluated company invested a lot of money and technology to improve its operation efficiency and service quality. But factually the core competence of it is not as high as expected. According to investigation, the reasons accounting for it might be as follows. On the one hand, although the parent company has invested a lot of capital and manpower on it for better development, many projects are still under way and the resources that can be used in operation are limited due to the long term of cold-chain logistics equipment construction. On the other hand, the company is specialized in special container business. China has been lack of containers and specialized automobiles for a long time. With deepening of the economic transition, the need in this field will be expanded. The total amount and structure of the special containers can only adapt to but not meet the need. The above two reasons may account for the fact that the company is not among the best in the top 50 cold-chain logistics enterprises recommended by the National Cold-chain Logistics Alliance of China. Even so, the company has taken advantage of its resources to satisfy its customers and improve its service quality to the largest degree. And therefore it is believed that the core competence of the company will be improved after the coldchain projects are finished and come into service which cannot only help the company gain fat profit but accelerate the local economy.

\section{CONCLUSION AND POLICY PROPOSALS}

Cold-chain logistics industry is still in the stage of development in China. The core competence of domestic cold- chain logistics needs to be improved. Based on investigation and research, several suggestions for development of coldchain logistics enterprises are put forward.

First of all, take advantage of flexible ways of financing and strengthen resource integration. Cold-chain logistics industry is low temperature logistics process based on cooling technology. A large number of capital and technology support is needed in order to improve the core competence of the cold-chain logistics enterprises. Cold-chain logistics enterprises can rely on supply chain finance business of banks for financing [11]. It cannot only activate the cold-chain logistics enterprises but also help operation of the whole "chain" thus to improve competence of the enterprises.

Secondly, offer services based on customer value and improve value-added services. The present market is customer-guided and therefore the core competence of coldchain enterprises is closely related to their service capability [12]. The enterprises can expand businesses such as freight forwarding, processing and packaging to meet customers' requirement. The improvement of service will benefit reputation of an enterprise, improve its image and enhance its core competence.

Finally, improve information technology relying on network construction. In recent years, a great deal of trade is carried out online. Application of information technology will help cold-chain logistics enterprises manage online order data and maximize resource profit by automatic inventory management in the process of logistics operation. Therefore, it is of great importance to construct network platform and introduce advanced information technology.

In brief, with better understanding of their current situations, the cold-chain logistics enterprises should improve their capacity of integrating various resources, enhance customer satisfaction and increase informatization so as to improve the core competence eventually.

\section{CONFLICT OF INTEREST}

The authors confirm that this article content has no conflict of interest.

\section{ACKNOWLEDGEMENTS}

This work is supported by the National Science Fund of China (No. 71473167). 


\section{REFERENCES}

[1] L. J. Kan, and B. Liu, "Analysis of development strategies of domestic cold-chain logistics," E-business Journal, vol. 8, pp. 5-6, (In Chinese), 2014.

[2] Q. G. Wu, "On the present development and strategies of domestic cold-chain logistics," China Business and Market 2, pp. 24-28, (In Chinese), 2011.

[3] C. X. Li, "The constraints and strategies of core competence of domestic logistics enterprises," vol. 1, pp. 42-44,(In Chinese), 2009.

[4] W. Luo, and B. Tan, "On performance evaluation indicators and approaches of logistics enterprises," Guangxi Journal of Logistics Enterprises, vol. 124, no. 3, pp. 123-125, (In Chinese), 2009.

[5] L. J. Yan, Y. Jiang, and Y. Wang, "Development of performance evaluation of logistics enterprises," Contemporary Economics, vol. 8, pp. 54-55, (In Chinese) 2009.
[6] J. E. Chang, and T. L. Jiang, "On determining weight by AHP," Journal of Wuhan University of Technology, vol. 29, no. 1, pp. 153-156 (In Chinese), 2009.

[7] J. Y. Guo, "Research and application of AHP," China Safety Science Journal, vol. 5, pp. 55-59, (In Chinese), 2008.

[8] Y. F. Wei, "On performance evaluation of cold-chain logistics," Hebei University of Economics and Business, (In Chinese), 2012.

[9] X. J. Wei, "Application of fuzzy clustering method in logistics performance evaluation," Logistics Technology, vol. 8, pp. 29-32, (In Chinese), 2003.

[10] Y. H. Hu, "Comprehensive evaluation method," Beijing: China social press. (In Chinese) 2000.

[11] X. Z. Zheng, Q. Tao, and J. X. He, "Research and application of supply chain financing risk analysis model," Logistics Management, vol. 712, no. 49, pp. 30-32, (In Chinese),2012.

[12] L. Wu, L. J. Zhang, and X. He, "Core competitive advantage recognition research of the third-party logistics enterprise based on customer value," Logistics Technology, vol. 1, pp. 121-125, (In Chinese) 2014.

(C) Jian and Jing; Licensee Bentham Open.

This is an open access article licensed under the terms of the (https://creativecommons.org/licenses/by/4.0/legalcode), which permits unrestricted, noncommercial use, distribution and reproduction in any medium, provided the work is properly cited. 